\title{
INNOVATION OF LEARNING METHODS DURING THE COVID-19 PANDEMIC AT JUNIOR HIGH SCHOOL IN MATARAM CITY AND WEST LOMBOK REGENCY
}

\author{
Fidiani Fidiantara, Ayudya Lestari*, Norma Juniati, Abdul Syukur, and Jamaluddin \\ Master of Science Education Study Program, University of Mataram, Mataram, Indonesia. \\ *Email: ayudya3800@gmail.com
}

Acceped: July 28 2021. Approved: July 31 2021. Published: Sept 042021

\begin{abstract}
Learning innovation is a solution to achieve learning mastery, especially during the covid-19 pandemic. This study aims to describe and assess models of learning innovation methods that are relevant to changes in learning models during the covid-19 pandemic. The method used in this research is descriptive method and the sampling technique is simple random sampling. Meanwhile, the data collection techniques used documentation studies and interviews. Data analysis in this study was descriptive statistics andtest one-way anova using software spssversion 17.0. The results showed that: 1) the innovation of learning methods during the covid-19 pandemic with blended learning showed a sig.> 0.05 value, namely 0.428 at junior high school mataram city and 0.442 at junior high school West Lombok Regency, which means there is no significant difference in the implementation of the learning method. Blended learning during the covid-19 pandemic; 2) teacher perceptions based on 5 indicators, namely learning methods, innovation in the learning process, use of technology, lesson planning, and teacher support capacity indicate that science teachers at junior high school mataram city and west lombok regency have perceptions of $87.5 \%$ and $75.0 \%$ with good category; 3 ) students' perceptions based on 5 indicators, namely the effectiveness of the methods used, the use of technology, learning activities, learning motivation, and the carrying capacity of facilities and infrastructure indicate that students at junior high school mataram city have a perception of $90 \%$ with a good category and west lombok regency of $72.5 \%$ with good enough category. The conclusion of this study is that learning innovation or a combination of methods through online learning methods with blended learning during the covid-19 pandemic is a solution to achieve student learning mastery.
\end{abstract}

Keywords: innovation, learning methods, covid-19

\section{INTRODUCTION}

Corona virus disease 2019 (covid-19) was first identified in whan city, hubei province, china on december 8, 2020 [1-3]. The disease that causes acute respiratory infections that attack the lungs has now hit 215 countries with indonesia being ranked 23rd [4-5]. The spread of covid-19 can be through direct contact or through fluids that come out of the patient's body that has been exposed to objects such as tables, chairs, iron, and others. Covid-19 transmission can occur from humans, human objects, and animals-humans who have been exposed to covid-19 before. This makes community social activities considered the highest risk in the spread of covid-19 [6]. Therefore, this pandemic has become a challenge for every country, including indonesia.

The covid-19 pandemic has resulted in changes in various aspects of life, especially in the field of education [7]. It was noted that since mid-march 2020, schools in indonesia have no longer held direct (offline) learning processes [8]. Based on the direction of the ministry of education and culture, the government has prohibited universities from conducting lectures directly (offline) and ordered them to carry out lectures or learning indirectly (online) [9]. With instructions these, all educational institutions in indonesia must prepare educational services that are in accordance with the current situation and conditions, namely indirect / online learning [10].

The online learning method is one solution to overcome the limitations of the current learning process. According to [11] online learning has a very significant impact oninterest learning learners, because previously there is no culture of distance learning applied in schools. Whereas according to [12], students are the main focus in learning, which must be independent and responsible for their learning. The results of research on online learning conducted by [13] on science learning during the covid-19 pandemic period at uin sunan ampel surabaya, as many as $30 \%$ of students thought online learning was not as expected. It is different from the results of research on students of english language study program at uin mataram, that online learning has a positive impact so that it also has an impact on increasing the value obtained by students.

Science learning is the main lesson that students must learn, from elementary school to university level. Science is a human effort to understand the universe through precise observations on objects, using procedures andexplanations logical so that a valid conclusion is obtained [14-15]. Science learning should be carried out properly and juxtaposed with practicum in school laboratories, considering the importance of these lessons [16]. Science learning is said to be 
successful if all the learning objectives that have been determined can be achieved. However, in reality, with this pandemic, the learning process has experienced several difficulties, one of which is in representing science materials in daily life, which previously could be done through practicum in the laboratory. The solution to this problem is by choosing the right learning method, one of which is blended learning combined with guided discovery which can improve understanding of concepts science students'[17].

Understanding of concepts, facts, procedures and skills is one indicator of mastery learning, especially in learning science. Where in science learning must be able to develop abilities [18]: 1) exploration and investigation, in the process students observe and investigate natural objects and phenomena, 2) develop basic science process skills namely, observing, measuring, using numbers, and communicating results observation, 3) develop curiosity, pleasure and want to carry out discovery activities, and 4) provide knowledge about objects, both characteristics, structures, and shapes. It is hoped that the currently chosen method will be able to achieve complete science learning, even in a pandemic condition.

Almost all educational institutions in indonesia carry out online learning processes, as well as educational institutions in the province of ntb. This is the most logical alternative in responding to the covid-19 pandemic [19]. In this case, online learning has been running for approximately 3 semesters, and has produced various levels of achievement. Learning outcomes during the covid19 pandemic are directly and indirectly influenced by several factors including: 1) infrastructure which is the main pillar of learning implementation, 2) teacher mastery of a variety of learning methods, and 3) teacher pedagogic abilities [20-22]. Meanwhile, the problem of using learning methods during the covid-19 pandemic, especially in study locations and its effect on students' learning mastery, has not yet beenassessed comprehensively. Therefore, research is needed related to the learning method model used and its effect on students' learning mastery. Furthermore, the purpose of this study is to describe and assess the innovation model of learning methods during the covid-19 pandemic at junior high school in mataram city and west lombok regency. The results of this study are expected to be a solution in developing learning methods to achieve student learning mastery during the covid-19 pandemic, especially at schools in study locations and other schools in west nusa tenggara province. This research can be used as an initial basis in carrying out further research.

\section{RESEARCH METHODS}

This research is a quantitative descriptive research. The purpose of the study was to describe the completeness of learning outcomes as well as the perceptions of teachers and students on learning methods during the covid-19 pandemic. The research variable is the completeness of learning outcomes. The study population consisted of all students at junior high school mataram city and west lombok regency. The research sample was students with a total of 261 people at junior high school mataram city and 241 people at junior high school West Lombok Regency. This research was conducted from 24 may to 05 june 2021 at junior high school in mataram city which consisted of junior high school 1 mataram, junior high school 7 mataram, junior high school 9 mataram and junior high school 14 mataram, while junior high school in west lombok regency consisted of junior high school 2 lingsar, junior high school 3 gunungsari, junior high school 3 lingsar and junior high school 1 kuripan.

The sampling technique in this study is simple random sampling. The data collection technique uses a documentation study to obtain the completeness value of science learning outcomes and the interview method uses an interview sheet with a score based on the likert scale to obtain information on the perceptions of teachers and students regarding the implementation of learning methods during the covid-19 pandemic. The data analysis technique for mastery of science learning outcomes was analyzed using thetest one-way anova on software spssversion 17.0 for windows with the aim of finding out where the differences in student learning outcomes were through the implementation of online learning methods with testing criteria. If the value of sig. $<0.05$ indicates there is a difference, otherwise if the value of sig.> 0.05 indicates there is no difference. Meanwhile, the perception data of teachers and students were analyzed descriptively using the percentage equation (\%). Data on the perception of teachers and learners are categorized based on the following intervals.

Table 1. Interpretation of teacher and student perception data

\begin{tabular}{ll}
\hline Interval score $(\%)$ & Category \\
\hline $75.01-100.0$ & Good \\
$50.01-75.0$ & Good enough \\
$25.01-50.0$ & Poor \\
$0.00-25.0$ & No good \\
\hline
\end{tabular}

\section{RESULTS AND DISCUSSION}

[23]

Learning methods carried out during the covid19 pandemic both at junior high school in mataram city and in west lombok regency throughlearning online and offline. Thelearning method online is one method of teaching students to form 
independent characters and understand the importance of managing learning time in achieving learning goals [24]. Therefore, a teacher or educator should have knowledge and metacognitive strata in order to achieve effective learning [25].

\section{Teacher}

Perceptions science teachers' perceptions of junior high school in mataram city and west lombok regency showed different results. The perception value of science teachers on the implementation of online learning methods is 87.5 good categories, technology use is $87.5 \%$ good category, lesson planning is $87.5 \%$ good category, and teacher support capacity is $100 \%$ good category. Thus, the perception of science teachers in mataram city shows good results compared to science teachers in west lombok regency. Meanwhile, innovations in the online learning process $(100 \%$, good) attempted by science teachers in west lombok regency showed good results. This is because science teachers in west lombok regency carry out an innovation through visits to students' homes in the hope of maximizing the knowledge transfer process.

Table 2. Teachers' perceptions of online learning methods with blended learning

\begin{tabular}{lcccc}
\hline \multicolumn{2}{c}{ Aspects of assessment } & \multicolumn{2}{c}{ Mataram city } & \multicolumn{2}{c}{ West lombok } \\
& Score & Category & Score & Category \\
\hline Learning method & 87.5 & Goodgood & 62.5 & Enough \\
Innovation in the learning & 62.5 & Good enough & 100 & Good \\
process & 87.5 & Good & 50 & Good enough \\
Use of technology & 87.5 & Good & 62.5 & Good enough \\
Learning planning & 100 & Good & 100 & Good \\
Teacher support capacity & & & & \\
\hline
\end{tabular}

The learning methods used by teachers both in the city of mataram and west lombok, namely themodel blended learning. The definition of blended learning can be interpreted as a learning that combines offline or face-to-face methods and online methods [26] at the same time, with the aim of balancing the shortcomings of the two methods to create optimum learning [27]. On the other hand, blended learning can refer to the combination of a number of different learning environments. For teachers and students, blended learning can be a solution to build an effective learning environment [28].

The implementation oflearning is blended not merely a combination of offline and online learning, but there are several important things to understand related to learning arrangements or known as synchronous and asynchronous. Learning arrangements can be interpreted as a condition regarding learning activities so that they can take place. Based on this, setting learning in themodel blended learning can be adapted to the perceptions and innovations of each teacher. Where for teachers in the city of mataram and west lombok, science learning arrangements are carried out by holding science practicum at home independently which is then presented online through the media that has been prepared.

\section{Students' Perceptions}

The results of the analysis of students' perceptions of learning methods show perceptions that tend to be the same both at junior high school in mataram city and west lombok regency as presented in table 3 .
Based on table 3 above, participants' perceptions students at junior high school mataram city on the effectiveness of the methods used, the use of technology, active learning, learning motivation, and the carrying capacity of facilities and infrastructure showed good results. Meanwhile, the perception of students at junior high school west lombok regency on learning motivation and the carrying capacity of facilities and infrastructure shows sufficient results. Differences in perceptions of learning motivation mean that students at junior high school mataram city have better motivation to learn during the covid-19 pandemic and this is supported by the completeness and availability of learning facilities and infrastructure through online or online learning methods, but this is not the case with students. At junior high school west lombok regency. According to [29] effective online teaching practice is based on a face-to-face practice framework and this requires teaching strategies that develop the creation of an environment that supports student activity. However, the advantages of online learning due to the covid-19 pandemic provide a more positive attitude towards the learning environment in the classroom [30]. During the implementation of learning methods, there are online often obstacles faced by students, one of which is not yet available internet connection and the lack of technological devices, but on the other hand, even though there is easy access to resources, students are still reluctant to use them sustainably in the future [31-32]. It takes adaptation of teaching online that must be gradually integrated into education that depends on the characteristics of students [30]. The results of the review of students' 
perceptions of learning method innovations should be used as evaluation materials in improving the quality of learning by choosing varied strategies [31-33]. Some of the benefits of online learning for students are that they can take part in learning without having to come to school. This is in line with the opinion [34] that the implementation of online learning is a new experience that brings breadth and ease in learning without having to go to school. Students can participate in learning as long as they have a good internet connection.

Table 3. Students' perceptions of online learning methods with blended learning

\begin{tabular}{lcccc}
\hline \multicolumn{1}{c}{ Aspects of assessment } & \multicolumn{2}{c}{ Mataram City } & \multicolumn{2}{c}{ Regency West lombok } \\
& Score & Category & Score & Category \\
\hline Effectiveness perceived method & 87.5 & Good & 87.5 & Good \\
Use of technology & 100 & Good & 75 & Good \\
Learning activity & 87.5 & Good & 75 & Good \\
Learning motivation & 75 & Good & 62.5 & Good enough \\
Capacity of facilities and infrastructure & 100 & Good & 62.5 & Good enough \\
\hline
\end{tabular}

\section{Completeness of Learning}

The outcomes results of data analysis showed that the data on completeness of learning outcomes at junior high school in mataram city and west lombok regency were distributed normallyand homogeneous. Based on the results of the analysis using one-way anova, it is known that there is no difference in learning outcomes using the online learning method at junior high school in mataram city with the value of sig. 0.428> 0.05 which is presented in table 4.

Learning outcomes at junior high school in mataram city and west lombok regency showed no significant difference after students were taught using online learning methods. This result can be strengthened by comparing the average value of learning outcomes before and during the covid-19 pandemic as presented in figure 1 .
Based on figure 1, it is known that the mastery of student learning outcomes in science subjects at junior high school in mataram city increased by 0.8 by using online learning methods. Although the increase is not large, learning activities during the covid-19 pandemic provide a different learning atmosphere for each educational unit in mataram city. Meanwhile, junior high school in west lombok regency experienced an increase and decrease in science learning outcomes during the covid-19 pandemic, as happened in several junior high school in mataram city. However, the overall completeness of science learning outcomes at junior high school in west lombok regency increased by 1.0 using online learning methods during the covid-19 pandemic.

Table 4. Results of completeness analysis of junior high school learning outcomes in mataram city

\begin{tabular}{lrrrrr}
\hline & \multicolumn{2}{c}{ Anova } & & \\
& Sum of squares & Df & Mean square & F & Sig. \\
\hline Between groups & 213,185 & 1 & 213,185 & .630 & $\mathbf{. 4 2 8}$ \\
Within groups & 89635,306 & 265 & 338,246 & & \\
Total & 89848,491 & 266 & & \\
\hline
\end{tabular}

Meanwhile, the results of the analysis of mastery learning outcomes at junior high school in lombok regency show a value of sig. $0.442>0.05$ that there is no difference in learning outcomes using online learning methods. Presented in table 5 .

Table 5. Completeness of junior high school learning outcomes in west lombok regency

\begin{tabular}{lrrrrr}
\hline & \multicolumn{2}{c}{ Anova } & & & \\
& Sum of squares & Df & Mean square & F & Sig. \\
\hline Between groups & 45,071 & 1 & 45,071 & 5,592 & $\mathbf{4 4 2}$ \\
Within groups & 18029,364 & 237 & 76,073 & & \\
Total & 18074,435 complete & 238 & & \\
\hline
\end{tabular}




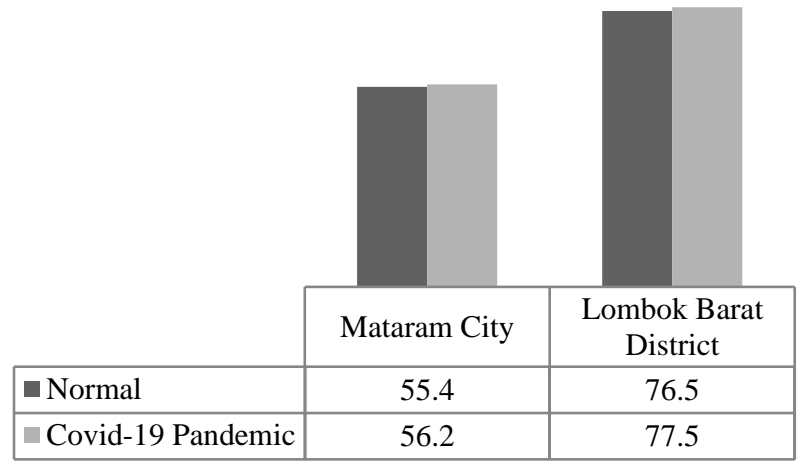

Figure 1. Graph of average learning outcomes at junior high school in mataram city and west lombok regency

The completeness of science learning outcomes at both mataram city junior high school and west lombok regency junior high school can be said to have increased using online learning methods during the covid-19 pandemic. The results of this study are in line with the results of research by [35] which revealed that "we found that online education during the pandemic increased students' academic outcomes by 0.22 in terms of standard deviation..." [35]. From some of the opinions of science subject teachers, it was stated that there were several reasons that led to better end-ofsemester assessments of students during a pandemic including: a) the learning burden of students was reduced during the covid-19 pandemic; b) the government restricts students from completing all $\mathrm{kd}$ bills; and c) learning resources are not enough just to use textbooks, but students can freely search for other relevant sources of information that support learning activities. Although in general the science learning outcomes at junior high school mataram city and west lombok regency have increased, but the science learning outcomes at junior high school West Lombok Regency are higher than junior high school Mataram Citywith a difference in score of 21.1 before the covid-19 pandemic and during the covid-19 pandemic. Of 21.3. This is because the end of semester assessment questions during the covid-19 pandemic in mataram city were compiled by the education and culture office. While the questions for the end of semester assessment in west lombok regency are compiled by the education level unit in this case the science subject teachers who are designed in such a way as to follow the criteria or abilities of students.

Allo [36] conducted research through a qualitative approach to identify perceptions of students' abilities towards online learning during the covid-19 pandemic. In his research, it was found that students were very enthusiastic about receiving learning materials in the form of voice notes or voice notes as one of the learning media in the classroom. Another study by [37] conducted in uae public schools that some electronic-based learning was in fact effective in helping smooth distance learning during the covid-19 pandemic. Meanwhile, the readiness of the education system and the closeness of teachers and students through online teaching before the covid-19 pandemic was known to provide convenience in conveying ideas or ideas [38]. According to [39-40] distance learning on student attitudes turned out to be positive. Thus, technology-assisted learning has a positive influence on students' abilities both before and during the covid-19 pandemic.

\section{CONCLUSION}

Based on the results of the analysis, it was concluded that the innovation of learning methods during the covid-19 pandemic with blended learning showed a sig.> 0.05 value, namely 0.428 at junior high school Mataram City and 0.442 at junior high school West Lombok Regency, which means there is no significant difference in the implementation of thelearning method blended learning during the covid-19 pandemic, this also means that the implementation of thelearning method blended learning can maintain the completeness of student learning outcomes even during the covid-19 pandemic.

\section{ACKNOWLEDGMENTS}

The authors would like to thank the master of science education study program, university of mataram for providing support through courses independent study. Furthermore, we would like to express our gratitude to the science teachers at junior high school mataram city and west lombok regency, as well as all parties involved in helping this research.

\section{REFERENCES}

[1] Worldmeters. 2020. Covid-19 Coronavirus Pandemic. 
Https://Www.Worldometers.Info/Coronavirus/ ?. (13 Agustus 2020).

[2] Sajadi, M. M., Habibzadeh, P., Vintzileos, A., Shokouhi, S., Miralles-Wilhelm, F., \& Amoroso, A. (2020). Temperature, Humidity, And Latitude Analysis To Estimate Potential Spread And Seasonality Of Corona Virus Disease 2019 (Covid-19). Jama Network Open, 3(6), E2011834-E2011834.

[3] Morawska, L., \& Milton, D. K. (2020). It Is Time To Address Airborne Transmission Of Corona Virus Disease 2019 (Covid-19). Clinical Infectious Diseases, 71(9), 2311-2313.

[4] Yunus, N, R., \& Annissa, R. 2020. Kebijkan Pemberlakuan Lockdown Sebagai Antisipasi Penyebaran Corona Virus Covid-19. Jurnal Sosial \& Budaya Syar-I. 7(3), 227-238.

[5] Ivorra, B., Ferrández, M. R., Vela-Pérez, M., \& Ramos, A. M. (2020). Mathematical Modeling Of The Spread Of The Coronavirus Disease 2019 (Covid-19) Taking Into Account The Undetected Infections. The Case Of China. Communications In Non Linear Science And Numerical Simulation, 88, 105303.

[6] Rahmi, R. (2020). Inovasi Pembelajaran Di Masa Pandemi Covid-19. Al-Tarbiyah: Jurnal Pendidikan (The Educational Journal), 30(2).

[7] Erni, S., Rian, V., Cut, R, M., Zubaidah, A, M, Z., Martius, \& Musa, T. 2020. Refleksi Proses Pembelajaran Guru Mts Dimasa Pandemi Covid 19 Di Pekanbaru: Dampak Dan Solusi. Bedelau: Jurnal Of Education And Learning. 1(1), 1-10.

[8] Setiawan, A, R. (2020). Lembar Kegiatan Literasi Saintifik Untuk Pembelajaran Jarak Jauh Topik Penyakit Coronavirus 2019 (Covid-19). Edukatif: Jurnal Ilmu Pendidikan. 2(1), 28-37.

[9] Kemendikbud. (2020). Kebijakan Merdeka Belajar Dalam Penentuan Kelulusan Peserta Didik Dan Pelaksanaan Penerimaan Peserta Didik Baru Tahun Ajaran 2020/2021. Jakarta.

[10] Ayuni, D., Marini, T., Fauziddin, M., \& Pahrul, Y. (2020). Kesiapan Guru Tk Menghadapi Pembelajaran Daring Masa Pandemi Covid-19. Jurnal Obsesi: Jurnal Pendidikan Anak Usia Dini. 5(1), 414-421.

[11] Purwanto, A., Pramono, R., Asbari, M., Hyun, C. C., Wijayanti, L. M., \& Putri, R. S. (2020). Studi Eksploratif Dampak Pandemi Covid-19 Terhadap Proses Pembelajaran Online Di Sekolah Dasar. Edupsycouns: Journal of Education, Psychology And Counseling. 2(1), $1-12$.

[12] Kusuma, J, W., \& Hamidah. 2020. Perbandingan Hasil Belajar Ipa Terpadu Dengan Penggunaan Platform Whatsapp Group Dan Webinar Zoom Dalam Pembelajaran Jarak Jauh Pada Masa Pandemi
Covid 19. Jurnal Ilmiah Pendidikan Ipa Terpadu. 5(1), 97-106.

[13] Rachmawati, Y., Muhammad, M., Ninik, F., Nailil, I., Khoirotul, U., Muhamaad, N, F, S., Rela, A., Fahira, A, A, C., \& Aisyatul, A. 2020. Studi Eksplorasi Pembelajaran Pendidikan Ipa Saat Masa Pandemi Covid-19 Di Uin Sunan Ampel Surabaya. Indonesian Journal Of Science Learning. 1(1), 32-36.

[14]Zeidler, D. L. (2002). Dancing With Maggots And Saints: Visions For Subject Matter Knowledge, Pedagogical Knowledge, And Pedagogical Content Knowledge In Science Teacher Education Reform. Journal Of Science Teacher Education, 13(1), 27-42.

[15] Warnick, L. B. (2001). Education And The Latter-Day Saints In The Year 2000: Toward A Systematic Pre-Assessment Of Prospective Distance Education Students. The University Of Nebraska-Lincoln.

[16] Susanto, A.(2013). Teori Belajar Dan Pembelajaran Di Sekolah Dasar. Jakarta: Kencana Prenada Media Group.

[17]Fita, A. R. (2017). Peran Orang Tua Dalam Meningkatkan Prestasi Anak Di Perum Tanjung Raya Permai Kelurahan Pematang Wangi Kecamatan Tanjung Senang Bandar Lampung (Doctoral Dissertation, Uin Raden Intan Lampung).

[18] Suyanto, W. (2015). Strategi Pembelajaran. Jakarta: Kencana Media Group.

[19] Jariyah, I. A., \& Tyastirin, E. (2020). Proses Dan Kendala Pembelajaran Biologi Di Masa Pandemi Covid-19: Analisis Respon Mahasiswa. Jurnal Penelitian Dan Pengkajian Ilmu Pendidikan: E-Saintika, 4(2), 183-196.

[20] Rozhak, M. (2018). Analisis Profesional Guru Ipa Terhadap Peningkatan Kualitas Pembelajaran. Universitas Muhammadiyah Sidoarjo.

[21] Sudiasih, N. N., \& Margunayasa, I. G. (2020). Pengaruh Model Pembelajaran Group Investigation Melalui Lesson Study Terhadap Penguasaan Konsep Ipa. Indonesian Journal Of Educational Research And Review, 3(1), 125-135.

[22] Setiawan, R. (2020). Analisis Profil Literasi Sains Calon Guru Fisika Pada Materi Kalor Di Iain Palangka Raya (Doctoral Dissertation, Universitas Negeri Semarang).

[23] Nurhani, N. (2015). Analisis Persepsi Guru Dan Peserta Didik Terhadap Kualitas Bahan Ajar Fisika Kelas Xi Sma Negeri Di Kabupaten Pinrang. Jurnal Sains Dan Pendidikan Fisika, 10(3).

[24]Paolini, A. (2015). Enhancing Teaching Effectiveness And Student Learning Outcomes. The Journal Of Effective Teaching - An Online Journal Devoted To Teaching Excellence, 15(1), 20-33. Retrieved From 
Https://Files.Eric.Ed.Gov/Fulltext/Ej1060429. Pdf.

[25] $\overline{\mathrm{De}}$, B. (2018, February 4). Traditional Learning Vs. Online Learning. Retrieved From Learning Industry: Https://Elearningindustry.Com/TraditionalLearning-Vs-Online-Learning

[26] Widaningsih, I. (2019). Strategi Dan Inovasi Pembelajaran Bahasa Indonesia Di Era Revolusi Industri 4.0. Uwais Inspirasi Indonesia.

[27] Chaeruman, U. A. (2017). Pedati Model Desain Sistem Pembelajaran Blended. Panduan Merancang Mata Kuliah Daring Spada Indonesia.

[28] Yaumi, M. (2018). Media Dan Teknologi Pembelajaran. Jakarta. Prenadamedia Group.

[29] Darby, F. (2017). How To Be A Better Online Teacher - Advice Guide. (J. M. Lang, Editor, \& D. S. Chronicle, Producer) Retrieved From The Chronicle Of Higher Education: Https://Www.Chronicle.Com/Interactives/Adv ice-Online-Teaching.

[30] Xhelili, P., Ibrahimi, E., Rruci, E., \& Sheme, K. (2021). Adaptation And Perception Of Online Learning During Covid-19 Pandemic By Albanian University Students. International Journal On Studies In Education, 3(2), 103-111.

[31] Syauqi, K., Munadi, S., \& Triyono, M. B. (2020). Students' Perceptions Toward Vocational Education On Online Learning During The Covid-19 Pandemic. International Journal of Evaluation And Research In Education, 9(4), 881-886.

[32] Adnan, M. (2020). Research Article Online Learning Amid The Covid-19 Pandemic : Students , Perspectives. Journal of Pedagogical Sociology And Psychology, 2(1), 45-51. Https://Doi.Org/10.33902/Jpsp.Citation.

[33] Yulia, H. (2020). Online Learning To Prevent The Spread Of Pandemic Corona Virus In Indonesia. Online Learning To Prevent The Spread Of Pandemic Corona Virus Eternal (English Teaching Journal), 11(1), 48-56.

[34] Alchamdani, A., Fatmasari, Anugrah, E. R., Sari, N. P., Putri, F., \& Astina, A. (2020). The Impact Of Covid19 Pandemic On Online Learning Process In The College At Southeast Sulawesi. Jurnal Kesehatan Lingkungan, 12(1), 129-136. Https://Doi.Org/10.20473/Jkl.V12i1si.2020.12 9-136.

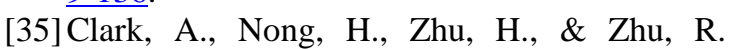
(2021). Compensating For Academic Loss: Online Learning And Student Performance During The Covid-19 Pandemic. China Economic Review, 101629.
[36] Allo, M. D. (2020). Is The Online Learning Good In The Midst Of Covid-19 Pandemic? The Case Of Efl Learners. Jurnal Sinestesia, 10(1), 1-10.

[37] Bawa'aneh, M. S. (2021). Distance Learning During Covid-19 Pandemic In Uae Public Schools: Student Satisfaction, Attitudes And Challenges. Contemporary Educational Technology, 13(3), Ep304.

[38] Al Salman, S., Alkathiri, M., \& Khaled Bawaneh, A. (2021). School Off, Learning On: Identification Of Preference And Challenges Among School Students Towards Distance Learning During Covid19 Outbreak. International Journal Of Lifelong Education, 1-19.

[39] Ayub, S., Makhrus, M., Sutrio, S., Gunada, I. W., \& Taufik, M. (2020). Inovasi Pembelajaran IPA (Fisika) di SD dengan Pemanfaatan Kit Alternatif dan Alat Sederhana yang Berasal dari Lingkungan. Jurnal Pijar Mipa, 15(1), 37-42.

[40] Malkawi, E., Bawaneh, A. K., \& Bawa'aneh, M. S. (2020). Campus Off, Education On: Uaeu Students' Satisfaction And Attitudes Towards E-Learning And Virtual Classes During Covid-19 Pandemic. Contemporary Educational Technology, 13(1), Ep283. 